\title{
Analysis on the Financing Dilemma and Countermeasures of China's Small, Medium and Micro Enterprises in the Information Age
}

\author{
Haiyang LI \\ School of Marxism, Anhui Sanlian College, Hefei, Anhui, China
}

\begin{abstract}
Expand financing channels for small, medium and micro enterprises, reduce loan costs, solve financing data matching, and improve financing efficiency. Analyze P2P financing model, e-commerce microfinance financing model, and online crowdfunding model. To a certain extent, the problems of narrow financing channels, high costs, high risks, and difficulty in applying for small, medium and micro enterprises have been alleviated. Using the ever-changing Internet technology to innovate the "Internet + " financing model, overcome the financing difficulties caused by insufficient government attention, discrimination in bank target selection, and the relatively small size of the enterprise itself, expand financing channels, and improve financing efficiency, Enabling small, medium and micro enterprises to get out of the "embarrassed" situation in which development is hindered by financing difficulties.
\end{abstract}

Keywords: Internet+, smallmedium and micro enterprises, financing, cost, model innovation

\section{Background}

With the active market economy and policy stimulus, in recent years, there has been an upsurge of "mass entrepreneurship and innovation" across the country, which has given birth to many Small, Medium and Micro enterprises. According to statistics, the number of Small, Medium and Micro enterprises in my country has reached 24 million, and the number of individual industrial and commercial households has exceeded 80 million. Their gross industrial output value accounts for $60 \%$ of my country's gross domestic product, and their contribution to national tax revenue exceeds 50\% [1]. Small, Medium and Micro enterprises are playing an increasingly important role in promoting economic growth, expanding employment, revitalizing entities, promoting innovation, prospering the market, maintaining social harmony and stability, and meeting people's growing needs for a better life. "It is difficult for a clever woman to cook without rice," and "capital" is the biggest obstacle to its development. The financing needs of small and micro enterprises are relatively large. Private lending is an important way to solve the financing difficulties of small and micro enterprises. However, small and micro enterprises and private loans as the main body of capital supply and demand hide major risks and disadvantages. When the financial resources obtained by Small, Medium and Micro enterprises from the formal financial system are not commensurate with the social benefits brought about by corporate development, innovating financing channels, alleviating their financing pressure, and breaking through their financing "bottlenecks" are of great significance and long way to go.

On March 14, 2021, the author conducted a search on CNKI on the topic of "Financing Issues for Small, Medium and Micro Enterprises". In the past 20 years, a total of 17,772 related papers were published.

According to the same theme and the annual presentation data of journal papers, it can be seen that the financing difficulties of Small, Medium and Micro enterprises need to be solved urgently. "It's hard for a clever woman to cook without rice," and even the best ideas will be "difficult to give birth" because of insufficient funds. Although the number of papers published in journals has decreased since 2015, the number of papers on "Internet + SME financing" has been increasing year by year in the context of the network information age. This shows that the "Internet +" financing method has a significant effect on the development of Small, Medium and Micro enterprises, and the attention has been increasing year by year in recent years.

ISSN: 0010-8189 
Today, "network information age", "new economic normal", "mass entrepreneurship and innovation" have become keywords in the new era. Whether Small, Medium and Micro enterprises can continue to develop in a healthy and stable manner is also a key step in the "supply-side structural reform". Whether they can grow and develop directly affects the development trend of the entire national economy. At present, in a situation where "Internet+" has become a national economic development strategy, researching and exploring the path choice of "Internet + financing for Small, Medium and Micro enterprises" is a new way and a good way to solve the financing difficulties of Small, Medium and Micro enterprises in the network information age.

\section{My Country's Small, Medium and Micro Enterprises' Financing Status and Analysis}

\subsection{The government's system flaws lead to narrow financing channels}

Premier clearly pointed out in his answer to questions from Chinese and foreign journalists at the Second Session of the 13th National People's Congress: "We are an independent choice to open to the outside world. All domestic enterprises of all types of ownership should be treated equally. Now, there is indeed a need to clear some of the loan issues Obstacles, guide financial institutions to improve their internal management mechanisms, run more private enterprises, small and micro enterprises, and help them reduce financing costs and reduce unreasonable expenses. Small and micro activities, economic viability, and more employment." [2] From here In the sentence, it is not difficult to see that small and micro enterprises play a significant role in social and economic development and employment. Although a series of institutional documents have been issued in recent years to support the development and financing of small and micro enterprises [3], they have not been implemented in the implementation and operation of the system. Refinement, there is still discrimination, and no "equal treatment" has been achieved. The government's introduction of institutional documents is not for viewing purposes. Government functional departments should not only pay attention to the drafting of the system, but also pay attention to the intensity of implementation and the effect of practice. Otherwise, policies will only become "spiritual incentives" rather than "material incentives." In addition, in the financing structure, my country has not yet formed a set of "all-round", "multi-level" and "wide-field" capital market financing systems and information-based financing platforms. At present, "financing channels mainly include internal financing and external financing" [4]. Endogenous financing mainly refers to the direct conversion of profits generated by the enterprise itself into capital for expanding reproduction. However, with the development of the times, internal financing is far from meeting the needs of Small, Medium and Micro enterprises to expand reproduction, and external financing has become an inevitable choice to support their rapid development. Some companies use considerable interest to stimulate internal managers or general employees to raise funds to achieve direct financing; some companies achieve direct financing through capital stocks, profit distribution, or issuance of bonds; some companies apply for bank guarantees by seeking financial intermediaries Loans achieve indirect financing; there are also companies that achieve indirect financing through private loans.

Considerable interest stimulates internal employees to raise funds, which is illegal; capital stocks and profit distribution are risky, unstable returns, and "difficult to realize". Intermediary guarantees to apply for bank loans due to its small scale, insufficient financial information, and complicated asset evaluation procedures., The amount of funds is small, the credit record is not sound, and the risk of fund recovery is high. Banks are dismissive of it and "unwilling"; private lending interest rates are too high. In today's mature market and fair competition, corporate profit margins are limited. Business owners are "not reconciled." The financing channels are naturally too narrow.

\subsection{Discrimination in the selection of bank targets, resulting in higher financing costs for micro-enterprises}

From the perspective of financial institutions: "Bank credit decisions mainly rely on'hard information' and'soft information'. Among them,' hard information' refers to the information that can be directly obtained through the 
financial status of the enterprise, business indicators, and credit ratings; while'soft information' It is information about the industry environment in which the company is located, the quality of corporate managers, and management capabilities." [5] Most of China's existing Small, Medium and Micro enterprises have been built in a short period of time. They are in terms of financing structure, financial statements, talent training and reserves, and operating information. Management systems and other aspects of information asymmetry with credit banks. At present, China's Small, Medium and Micro enterprises lack a unified credit information system, especially small and micro enterprises in order to be able to obtain bank financing, and there is a widespread phenomenon of altering or even forging financial statements, lacking the "spirit of contract." This leads to mistrust between each other. At the same time, in the fierce market competition, Small, Medium and Micro enterprises are easily squeezed by similar large-scale enterprises, and their own risk awareness is relatively poor, resulting in a relatively large bank investment risk, and high risk will inevitably generate high interest. In choosing loan targets, banks would rather choose large enterprises than ignore the "Small, Medium and Micro enterprises." Premier said: "Serving the real economy is the bounden duty of finance, but we do face the problem of the real economy, especially the private economy and small and micro enterprises, that financing is difficult and expensive." [6] Therefore, object selection discrimination speaks for itself.

From the perspective of Small, Medium and Micro enterprises themselves: the development of enterprises cannot do without capital. At present, my country's Small, Medium and Micro enterprises lack funds due to the selective discrimination of bank loan targets. In addition, their production scale is small, the management system is not systematic and scientific, the equipment is not advanced enough, and the talent pool is inevitably insufficient, which leads to weak innovation capabilities. Large and medium-sized enterprises are relatively "weak" in market competition. Due to lack of funds, there is a lack of professional teams (including financial teams and scientific research teams), which will lead to higher risks in the process of economic operation, and the ability of enterprises to bear and avoid risks is weak, which will inevitably lead to their products in the market China's competitiveness is not strong, and a vicious circle between "production" and "sales" appears. Therefore, in order to enhance the overall strength of the enterprise, most of the Small, Medium and Micro enterprises have a high frequency of demand for funds, and they have high expectations for the bank's capital needs. However, due to the asymmetry of information, there is a lack of trust between it and the bank. Before a loan, the bank needs the enterprise to provide the subject matter for asset mortgage, and conduct a systematic value and risk assessment of the enterprise. The cost paid by banks for investigations of Small, Medium and Micro enterprises is often 6-8 times that of large and medium-sized enterprises. "The wool is on the sheep". Banks will not pay for their own research costs, but they will adopt indirect methods to "pass on". "Research costs. Therefore, it will inevitably increase the loan interest rate or loan processing fees for Small, Medium and Micro enterprises. However, due to its simple procedures and low borrowing requirements, private lending may not even require a mortgage object or an intermediary guarantor, and its lending methods are also favored by Small, Medium and Micro enterprises. This borrowing method is generally a short-term capital turnover option. Because of its high interest rate, it is difficult for Small, Medium and Micro enterprises to bear the risks and pressures brought about by high costs.

\subsection{Small, Medium and Micro enterprises have high financing risks, making it difficult to apply for financing}

In order to invigorate the economy, enrich the market, increase employment, and meet the people's ever-growing needs for a better life, the government has insufficient restrictions on the development of Small, Medium and Micro enterprises, or even deliberately. For fear of a situation of "death at once, and chaos as soon as it is released".

Due to their large number, the supervision of their development process is certainly insufficient. The low standards and low requirements for market entry barriers make them obviously "weak" in today's "shopping mall like a battlefield". They have no capital advantage, but have no financial advantage. There is no technical advantage, and no advantage in scale. Because of its own weaknesses, it increases the risk of its operation, and its own ability to resist risks is weak. To achieve financing, it must be possible to attract others with high interest or high-value 
"collateral". s concern. Due to the small scale of Small, Medium and Micro enterprises, lack of large-scale property pledges, lack of professional teams, large fluctuations due to the influence of the market and the economy, and weak debt repayment ability, once the business is poorly managed, it is difficult to resolve the debt crisis, even if the mortgage is provided Assets, such as fixed assets, are often insolvent. Moreover, the valuation of fixed assets is more complicated, which is prone to disputes between creditors and debtors. In addition, the evaluation costs are high, it is difficult to mortgage here, and the bank can obtain approval there; In addition, banks do not trust the information related to business operations and financial statements when applying for loans to Small, Medium and Micro enterprises, and doubt the authenticity of the information. In order to avoid their own lending risks, banks often focus on investigating Small, Medium and Micro enterprises. The financing credit rating and financial status of the enterprise. This will inevitably lead to banks tending to large units rather than "small businesses". They would rather "hold your thighs" than ignore "little fingers."

Regarding the crux of the traditional financing methods of Small, Medium and Micro enterprises, even as Premier said: "multiple strategies and multi-pronged approach to reduce the financing costs of Small, Medium and Micro enterprises", the effect is unlikely to be immediate. Innovating the modern "Internet +" financing model may be a new path and new method to stop boiling water.

\section{Analysis of Internet Financing Modeis of Small, Medium and Micro Enterprises in the Network Information Age}

With the rapid development of science and technology, the popularization and application of the Internet continue to expand. Under the background of the information age where there is no Internet, and the economic development from industrialization to information and intelligence has become the general trend, the supply and demand of big data The use of technologies such as integration, cloud computing, and mobile payment over the air as a means to carry out network financing will surely become an inevitable product of the network information age. According to the development trend of Internet finance in recent years, we can classify the Internet financing models of Small, Medium and Micro enterprises into the following categories.

\subsection{P2P financing model}

P2P (peer to peer lending) lending, also known as "peer to peer lending", is a new type of financing method for both parties to borrow and lend to achieve direct lending relationships without banks and other financial institutions. Both parties to the borrower and lender can choose their trusted P2P financing platform according to their own needs, directly establish contact with the lending unit, and check the basic information of the lending unit's operating status, fixed assets, staffing, system construction, and development planning. Perform quantitative analysis on the strength of the lender, test the matching degree of the borrower and the lender, and finally decide whether to borrow" [7]; or appoint a professional lending platform related professional evaluation team as an agent to make a risk assessment of the lending unit, determine whether to borrow and the specific content of the lending contract. Of course, the latter P2P financing platform costs relatively high. During the contract, the borrowing and lending parties do not need to meet, and the materials, contracts, procedures, funds, etc. can all be completed through the Internet.

\subsection{E-commerce microfinance financing model}

The e-commerce micro-credit financing model is an Internet micro-credit model that relies on the e-commerce platform based on the platform main body to determine the past consumption and loan credit status of the lending unit, and then determine the loan limit [8]. This loan model is based on network technologies such as big data and cloud computing, and is the result of dynamic analysis of the static data of the borrower and the lender and the past transaction behavior on the basis of certain rules. Ali, JD.com, Suning, etc. are currently operating well in this model. Compared with the P2P financing model, the loan amount is small, loan review is fast, the credit risk is low, and the service is subject to many characteristics, and the operation mode is similar to that of "Ant Huabei".

ISSN: 0010-8189 


\subsection{Online crowdfunding model}

The online crowdfunding model means that the lending unit initiates crowdfunding with the help of the Internet financing platform according to its own needs, and the lending unit divides the equity according to the comprehensive operation and operation status of its own unit to obtain project financing [9]. Because it does not point to specific people, it overcomes the information asymmetry between borrowers and lenders, allowing ordinary people to participate in investment and entrepreneurship. At the same time, it can also share the borrowing risk.

\section{Advantages of Internet Financing}

\subsection{Expanded financing channels for Small, Medium and Micro enterprises}

With the development of the economy, the "mass entrepreneurship and innovation" under the new economic normal have become the "tide" of current economic development. "It is difficult for a clever woman to cook without rice." Relying only on traditional financing channels (such as banks, internal staff, private loans, etc.) can no longer meet the needs of the development of Small, Medium and Micro enterprises. "Internet+" realizes the diversification of financing methods while innovating the modern credit information system, which not only meets the investment needs between enterprises and enterprises, but also realizes the aspirations of "mass entrepreneurship" or opportunities for capital appreciation.

First, it broadens the financing platforms for Small, Medium and Micro enterprises, improves the financing environment, and expands the physical space for their development; second, it realizes the value of the Internet in the "Internet +" era, adding impetus to economic and social development in the information age; Finally, it opened up a new way for investors' capital appreciation [10].The realization path is shown in the figure below:

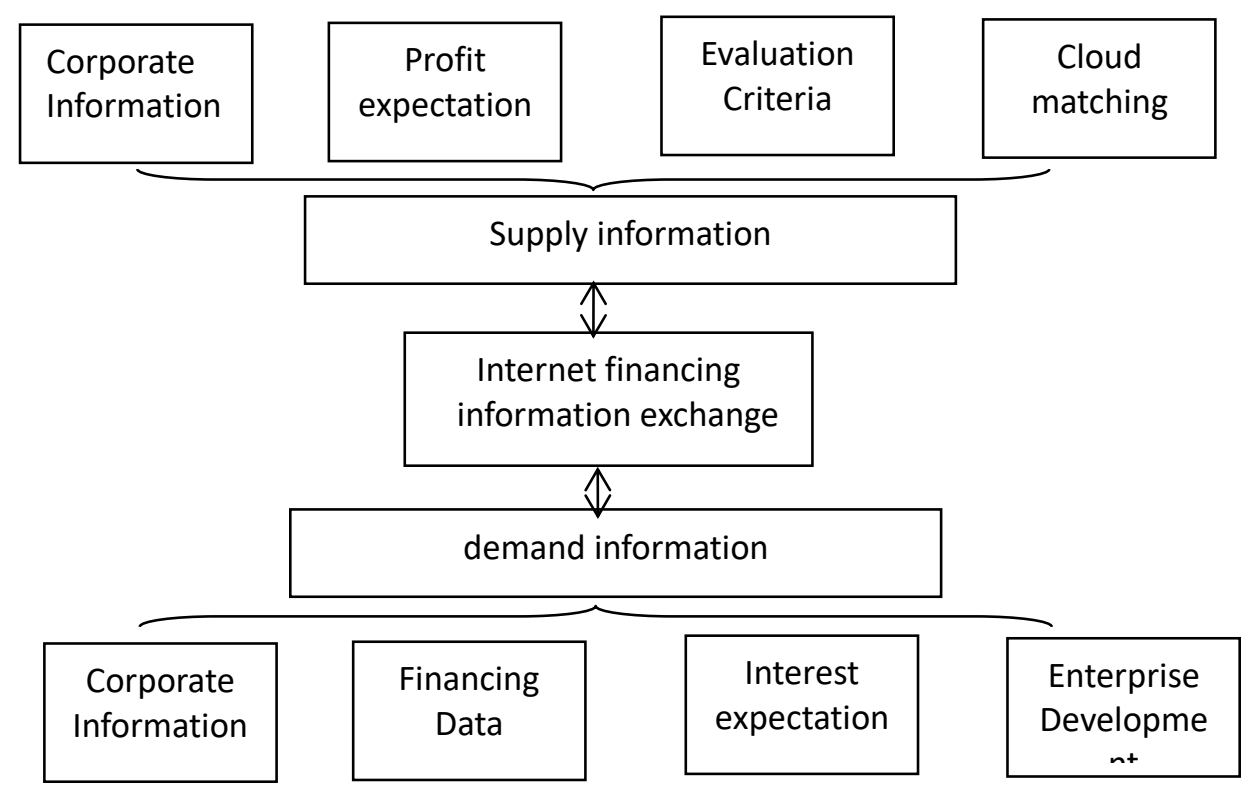

4.2 Effectively reduce the loan cost of Small, Medium and Micro enterprises

The Internet financing model has obvious advantages over traditional financing methods. Internet financing uses big data to integrate information, and then intelligently analyze user information through cloud computing, which greatly reduces the information asymmetry and mistrust of the borrower and lender. The cost of screening [11]; traditional financing can avoid all kinds of handling fees, transportation fees, office fees, reception fees, etc., while 
the Internet platform intelligent system can almost ignore these costs. At the same time, it can also shorten the financing time (hidden) cost of Small, Medium and Micro enterprises. In particular, private lending needs to be supervised and controlled, and should not be left unchecked. "When the government formulates relevant policies, first of all, it should change the long-term gray area of private lending, encourage private capital to actively participate in the formal financial investment field, and accept the current financial Regulations and financial supervision; secondly, we should continue to promote the reform of interest rate marketization, and promote the further marketization of private lending interest rates" [12], so as to reduce the financing pressure of Small, Medium and Micro enterprises and reduce their financing costs.

\subsection{Solved the problem of data matching between the financing parties of Small, Medium and Micro enterprises}

As a financial intermediary between the borrower and the lender, the bank does not have a deep understanding of the borrower and the lender. The bank will only intervene when the lending unit has a strong borrowing need, and the bank has no subjective willingness and obligation to send the supply and demand information of the borrower and the lender to the other party. Resulting in the loss of one's own credit business, leading to the problem of asymmetry in financing information [13]. The current narrow investment channels in our country (investments are mainly concentrated in real estate and other industries), making it difficult for Small, Medium and Micro enterprises as the real economy to lack development funds. When the government is curbing the real estate market today, the stock market is in a downturn, regardless of the supply side or the demand side has the intention to seek cooperation from the other side. At this time, the rise of the Internet has effectively resolved the information asymmetry between the supply and demand sides. As the demand side, Small, Medium and Micro enterprises can quickly find a matching supplier through the Internet financing platform.

\subsection{Improved the financing efficiency of Small, Medium and Micro enterprises}

"Whether it is traditional financing or Internet financing, its essence is to rationalize the distribution of capital flows, so that enterprises can achieve maximum benefits in the same time." [14] Time is money, time is efficiency, and Internet financing is under the circumstances of network informatization. Virtualizing and systematizing the funds and information of the supply side and the demand side facilitates effective matching on the current financing platform, so that the network review speed is faster, and there is no difference in time and space; the platform information classification system allows users to have a target; The financing data is intelligently matched, and the work is efficient; the financing cost is relatively low, and the willingness to seek cooperation is strong. Greatly improve financing efficiency.

\section{Conclusions}

Of course, we should also realize that solving the financing difficulties of Small, Medium and Micro enterprises is a complex and systematic project. Only the development of the "Internet +" financing model cannot fundamentally solve the financing difficulties of SMEs. Other policy measures are needed. Coordination requires multi-pronged efforts by the government, enterprises, and financing platform institutions, so that they can truly exert their best effects. Of course, the effectiveness of government policies is either ignored or indispensable. First, the government must adjust and optimize the financial structure, and allocate funds to the most efficient Small, Medium and Micro enterprises according to the marginal benefits of one point; second, it must develop multi-level and regional financial institutions, and at the same time regulate the capital lending market, and broaden the Small, Medium and Micro enterprises. Corporate financing channels; finally, Small, Medium and Micro enterprises should strengthen their own construction, enhance their image of integrity, build a credit system, and incorporate the lending relationship of Small, Medium and Micro enterprises into the national credit investigation system.

At the same time, when the government is formulating to resolve the "tensed" financing relationship between SMEs and borrowers, it is the first to "cut off" the long-standing gray area of private lending, allowing and encouraging 
private capital to actively participate in financial investment from the legal level, and accept the current situation. Financial legal constraints and supervision [15]; Secondly, the interest rate market reform of various small and medium financial institutions should be continuously promoted to gradually integrate with large financial qualifications; finally, Small, Medium and Micro enterprises and financing institutions should implement risk and transaction cost plus pricing Method, set the loan interest rate by yourself, of course, the fluctuation of interest rate must be legal in order to make the financial allocation more efficient.

\section{Acknowledgement}

This article passed field surveys of 28 small, medium and micro enterprises in five cities in China: Shanghai, Nanjing, Hefei, Wuhu, and Huainan, and received strong support from the Anhui Branch of the Bank of Communications of China. I would like to express my gratitude.

The Quality Engineering Major Project of the Department of Education of Anhui Province "Research on the Construction of the Practical Teaching System of Ideological and Political Courses in Private Undergraduate Colleges-Taking Anhui Sanlian College as an Example" (2018jyxm0988); The Quality Engineering Wisdom Class Pilot Project of the Department of Education of Anhui Province "Mao Zedong Thought" And Introduction to the Theoretical System of Socialism with Chinese Characteristics" (2017zhkt198).

\section{References}

[1] L. Hui, H Shaozhen. Comparative and innovative research on the Internet financing models of SMEs in my country . Contemporary Economics. 10: 38-40, 2018.

[2] 360 Baike. Premier Li Keqiang answered questions from Chinese and foreign journalists in 2019 EB/OL.https://baike.so.com/doc/28625498-30085987.html

[3] H. Qi. The Dilemma of Cooperation between Banks and Accounts in Financing of Small and Micro Enterprises__ Research on the Development of Financing Guarantee Industry in Henan Province. Financial Theory and Practice. 1: 47-54, 2019.

[4] C.Jing, H.Jinlin. Analysis on the Path of Internet Finance to Solve the Financing Difficulties of Small and Medium-sized Enterprises . Business Economics Research. 1: 172-175, 2019.

[5] C.Jing, H.Jinlin. Analysis on the Path of Internet Finance to Solve the Financing Difficulties of Small and Medium-sized Enterprises . Business Economics Research. 2019;1: 172-175.

[6] 360 Baike.Premier Li Keqiang answered questions from Chinese and foreign journalists in 2019 EB/OL.https://baike.so.com/doc/28625498-30085987.html

[8] W.Junji. Influencing factors of lending behavior based on P2P lending websites. Global Market Information Herald. 29: 49-53, 2014.

[8] W. Yixin. Research on the Financing of Small and Medium-sized Enterprises with the Integration of Internet Finance and Commercial Banks . Technology Economy and Management Research. 2: 78-83, 2017.

[9] L. Jingyi, X. Jing. Analysis of the Fiscal and Financial Policies to Promote the Financing of my country's Small and Medium-sized Enterprises. Journal of Chengdu University (Social Science Edition). 1: 40-45, 2018.

[10] D. Xuan. Research on the financing of small and medium-sized enterprises under the Internet finance model . Shandong Normal University. 2018.

[11] W. Zijing. Research on Financing Constraints, Shared Finance and the Growth of Small and Micro Enterprises. Shandong University. 2018.

[12] H.Yong, S. Jinghui, X.Ning. Summary of research on the development of small and micro enterprise financing and private lending . Journal of Hunan University of Technology (Social Science Edition). 3: 38-42, 2018. 
[13] SowHup.Financing of Micro and Small Enterprises in China, An Exploratory Study,Strategic Change, 22(7-8):431-446, 2013.

[14] L.Shuai, P.Zhongqing. Social capital, private finance and SME financing. Investment Research. (7): 148-159, 2017.

[15] Z,Wenxue. D. Xiaoli, Z. Jing. Research on the Factors Influencing the Effectiveness of Financing Guarantees for Chinese Small and Micro Enterprises_-Based on the Empirical Analysis of Jiangsu Guarantee Companies . Statistics and Information Forum. 1: 49-57, 2019. 